\title{
Expression of Different Types of Inward Rectifier Currents Confers Specificity of Light and Dark Responses in Type A and B Photoreceptors of Hermissenda
}

\author{
Ebenezer N. Yamoah, ${ }^{1,2}$ Louis Matzel, ${ }^{3}$ and Terry Crow ${ }^{2}$ \\ ${ }^{1}$ Department of Cell Biology, Neurobiology, and Anatomy, University of Cincinnati School of Medicine, Cincinnati, Ohio \\ 45267, and Marine Biological Laboratory, Woods Hole, Massachusetts 02543, 2Department of Neurobiology and \\ Anatomy, University of Texas Medical School, Houston, Texas 77030, and ${ }^{3}$ Rutgers University, Department of \\ Psychology, Busch Campus, New Brunswick, New Jersey 08903
}

Each eye of the mollusc Hermissenda consists of five photoreceptors, two type A and three type B cells. Type A cells are quiescent, whereas $B$ cells are spontaneously active in the dark. Differences in the intrinsic membrane properties of type $A$ and $B$ photoreceptors were studied using voltage- and currentclamp techniques. The current density of a $\mathrm{Ni}^{2+}$-sensitive, low-voltage activated $\mathrm{Ca}^{2+}$ current was similar in the two cell types. However, type B cells express an inward rectifier current $\left(I_{h}\right)$ that has different permeation and pharmacological properties from the inward rectifier current in type A cells. The current in the $\mathrm{B}$ cells was time-dependent and was blocked by $\mathrm{Cs}^{+}$. $\mathrm{Na}^{+}$and $\mathrm{K}^{+}$were the charge carriers for $I_{h}$. The inward rectifier current in A cells $\left(I_{\mathrm{K} 1}\right)$ was time-independent, was selectively permeable to $\mathrm{K}^{+}$, and was blocked by $\mathrm{Ba}^{2+} \cdot \mathrm{Ni}^{2+}$ reduced the spontaneous spike activities of type A and B cells, whereas $\mathrm{Cs}^{+}$produced membrane hyperpolarization and reduced the spike activities of dark-adapted B cells. The application of both $\mathrm{Cs}^{+}$and $\mathrm{Ni}^{2+}$ completely blocked dark-adapted spontaneous activities of $\mathrm{B}$ cells. Moreover, $\mathrm{Ba}^{2+}$ increased the excitability of type A cells but not $B$ cells. Hence, differential expression of the two distinct inward rectifiers found in type $A$ and $B$ cells contributes to differences in their intrinsic membrane properties. Because changes in the excitability of the two cell types are correlates of conditioning in Hermissenda, modulation of these underlying currents may play a major role during conditioninginduced plasticity.

Key words: Hermissenda; photoreceptors; calcium currents; inward rectifiers; membrane oscillation; neuronal plasticity
Alteration of membrane excitability of neurons is an example of cellular plasticity associated with learning in nervous systems of vertebrates and invertebrates (Abrams, 1985; Jester et al., 1995). The mollusc Hermissenda has a simple eye that serves not only as a site for photo transduction but also as a locus for cellular plasticity (Crow, 1988; Farley et al., 1990; Alkon et al., 1992; Matzel and Rogers, 1993). The eye consists of five photoreceptors that are classified as type A and B cells, based on anatomical and electrophysiological differences (Alkon and Fuortes, 1972). Classical conditioning of Hermissenda produces enhanced excitability of the B photoreceptors that is expressed as an increase in input resistance (Crow and Alkon, 1980; Crow, 1988; Matzel and Rogers, 1993) and a reduction of both the transient $\mathrm{K}^{+}$current $\left(I_{A}\right)$ and the calcium-activated $\mathrm{K}^{+}$current $\left(I_{\mathrm{K}, \mathrm{Ca}}\right)$ (Alkon, 1979; Alkon et al., 1985). In contrast, type A cells undergo a reduction in dark-adapted input resistance (Farley and Alkon, 1982; Farley et al., 1990). Differences between the two cell types are not only expressed in conditioned animals but can be seen in naïve animals as well.

Type A cells are quiescent in the dark, and type B cells undergo rhythmic spike activities in darkness. Light elicits depo-

\footnotetext{
Received March 16, 1998; revised May 21, 1998; accepted May 28, 1998.

This work was supported by a Grass Foundation fellowship to E.N.Y. and by National Institutes of Health grants to T.C. (MH40860) and L.M. We thank Dr. J. Byrne for the use of his osmometer during the initial phase of the experiments. We also appreciate constructive comments provided by Dr. N. Chiamvimonvat.

Correspondence should be addressed to Dr. Ebenezer N. Yamoah, Department of Cell Biology, Neurobiology, and Anatomy, University of Cincinnati School of Medicine, 231 Bethesda Avenue, Cincinnati, OH 45267.

Copyright (C) 1998 Society for Neuroscience $\quad 0270-6474 / 98 / 186501-11 \$ 05.00 / 0$
}

larizing generator potentials in both cell types. At the end of a light stimulus, the A cells remain electrically silent after a few seconds of dark adaptation, but the B cells remain tonically active (Alkon and Fuortes, 1972). The underlying mechanisms for the different electrical properties between the two cell types are unknown. Synaptic inhibition between the photoreceptors has been used, in part, to explain differences in the electrical properties of A and B cells (Alkon and Fuortes, 1972). However, such an explanation may not suffice to explain the properties of the two cell types. For instance, the A cells are relatively hyperpolarized in the dark-adapted state, whereas the B cells are more depolarized and remain spontaneously active; yet the inhibitory inputs at the B cells are stronger than are those at the A cells (Alkon and Fuortes, 1972).

Differential expression of different ionic currents in type A and B cells may contribute to the apparent electrophysiological differences between the two cell types. To examine this possibility, we studied ionic currents and electrical properties of the photoreceptors using the whole-cell voltage-clamp technique and conventional intracellular recordings. The properties of three distinct inward currents are presented. Type A and B cells express a transient $\mathrm{Ca}^{2+}$ current $\left(I_{\mathrm{Cat}}\right)$ at similar densities. But the A cells predominantly express a time-independent $\mathrm{K}^{+}$-permeable inward rectifier current $\left(I_{\mathrm{K} 1}\right)$, which tends to hyperpolarize the cells and prevent tonic activity in darkness. In contrast, type B cells exhibit a time-dependent $\mathrm{Na}^{+} / \mathrm{K}^{+}$-permeable inward rectifier current $\left(I_{h}\right) . I_{h}$ promotes membrane depolarization. The combined effects of $I_{\mathrm{Cat}}$ and $I_{h}$ support spontaneous activities of type $\mathrm{B}$ photoreceptors in the dark. 

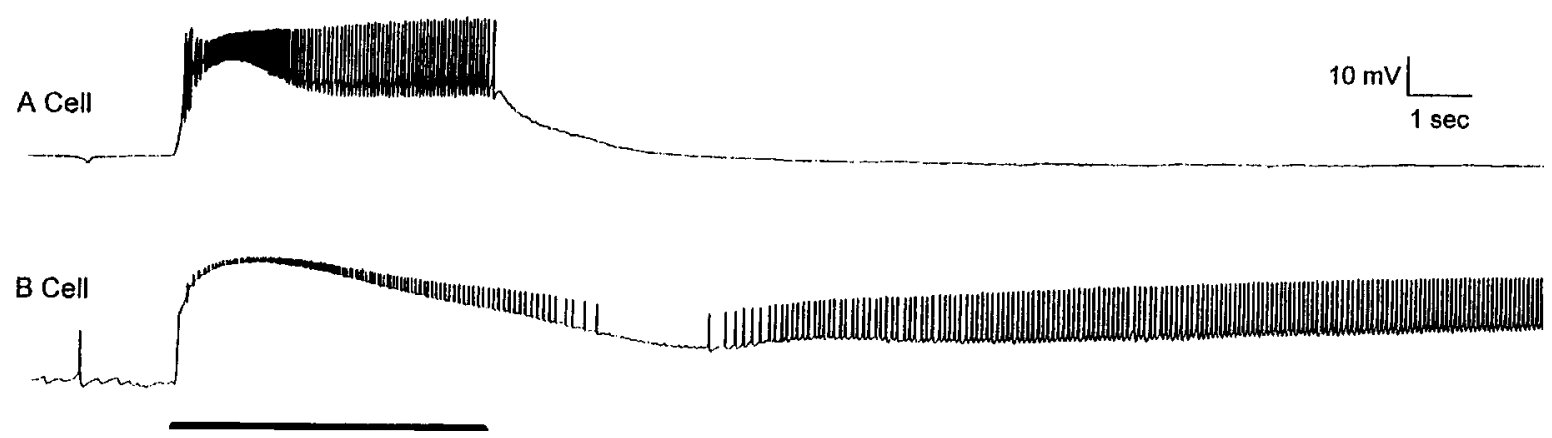

Figure 1. Differences in light- and dark-response properties of Hermissenda photoreceptors. Top, Voltage response obtained in a type A cell with a 5 sec light pulse (solid bar) is shown. The nervous system was bathed in artificial seawater, and the photoreceptor was impaled with an electrode containing a $3 \mathrm{M}$ potassium acetate solution. After attenuation of the light stimuli, the membrane potential of A cells typically drops to the resting potential and remains silent in darkness. Inhibitory synaptic potentials induced from adjacent photoreceptors can be recorded. Bottom, Type B cells continue to be tonically active in darkness. A $5 \mathrm{sec}$ light flash induces the characteristic membrane depolarization shown here. In contrast to A cells, B cells remain spontaneously active in the dark-adapted state.

\section{MATERIALS AND METHODS}

Cell isolation. Specimens of Hermissenda were obtained from Sea Life Supply (Sand City, CA) and housed in artificial seawater (ASW) tanks at $14-16^{\circ} \mathrm{C}$. Animals were fed scallops daily and maintained on a $12 \mathrm{hr}$ light/dark cycle. The photoreceptors of Hermissenda were freshly isolated from the nervous system, and the type A and B cells were identified according to methods described previously (Yamoah and Crow, 1994, 1996). The nervous systems were dissected and incubated in ASW (composition in $\mathrm{mm}$ is $420 \mathrm{NaCl}, 10 \mathrm{KCl}, 10 \mathrm{CaCl}_{2}, 22.9 \mathrm{MgCl}_{2}, 25.5$ $\mathrm{MgSO}_{4}$, and $15 \mathrm{HEPES}$, buffered to $\mathrm{pH} 7.8$ with $\left.1 \mathrm{~N} \mathrm{NaOH}\right)$ at $4^{\circ} \mathrm{C}$ for $10 \mathrm{~min}$ and then were exposed to an enzyme solution made of $7 \mathrm{mg} / \mathrm{ml}$ dispase grade II (Boehringer Mannheim, Mannheim, Germany) and 1 $\mathrm{mg} / \mathrm{ml}$ protease (Sigma, St. Louis, MO) in ASW for $10 \mathrm{~min}$ at $4^{\circ} \mathrm{C}$. The preparation was transferred to room temperature $\left(20^{\circ} \mathrm{C}\right)$ for another 7-10 min and then was washed several times with ASW at $4^{\circ} \mathrm{C}$. After incubation for $20 \mathrm{~min}$ at $4^{\circ} \mathrm{C}$, the eyes were isolated. Type A and B cells were identified on the basis of their position relative to the lens and the optic nerve. Therefore, isolated eyes without a lens and the stump of the optic nerve were discarded. We did not further classify isolated photoreceptors as either medial or lateral (Alkon and Fuortes, 1972). Using a fire-polished pipette, we isolated individual photoreceptors, plated them into $35 \mathrm{~mm}$ sterile culture dishes (Falcon, 1008; Fisher Scientific, Houston, TX) containing $2 \mathrm{ml}$ of gentamycin-treated ASW $(50 \mathrm{mg} / \mathrm{ml})$, and stored the dishes at $4^{\circ} \mathrm{C}$ (Yamoah et al., 1994). The solution was aspirated and replaced with recording medium 5 min before voltage-clamp experiments were performed.

Voltage clamp. Macroscopic whole-cell inward rectifier and calcium currents were recorded at room temperature $\left(20^{\circ} \mathrm{C}\right)$. All chemicals were obtained from Sigma unless otherwise noted. The compositions of the bath solutions for recording calcium and inward rectifier currents were as follows (in $\mathrm{mM}$ ): for the $\mathrm{Ca}^{2+}$ current, 400 tetraethylammonium (TEA) acetate or $400 \mathrm{~N}$-methyl-D-glucamine (NMG) and 200/250 TEAchloride, $10 \mathrm{CaCl}_{2}, 5 \mathrm{MgSO}_{4}, 5$ 4-aminopyridine, and $15 \mathrm{HEPES}, \mathrm{pH}$ 7.7, titrated with TEA-hydroxide (TEA-OH); and for the inward rectifier currents, $200 \mathrm{NMG}, 300$ choline chloride, 2-50 KCl, 0-2 $\mathrm{CaCl}_{2}, 50$ $\mathrm{MgSO}_{4}$, and $15 \mathrm{HEPES}, \mathrm{pH} 7.7$ (with $\mathrm{KOH}$ ). Experimental agents were applied by bath superfusion at a rate of $1-1.5 \mathrm{ml} / \mathrm{min}$ using gravity and an aquarium pump for suction (Penn-Pax Plastic, Garden City, NY) in a $1.2 \mathrm{ml}$ experimental chamber. The pipette solution contained (in $\mathrm{mm}$ ): for the $\mathrm{Ca}^{2+}$ current, $300 \mathrm{NMG}, 200 \mathrm{CsCl}, 50$ HEPES, 2-5 EGTA, 20 $\mathrm{NaCl}, 2 \mathrm{MgSO}_{4}, 20 \mathrm{TEA}, 5 \mathrm{MgATP}, 1 \mathrm{Na}_{2} \mathrm{GTP}$, and 10 reduced glutathione, $\mathrm{pH} 7.4$ (with TEA-OH); and for the inward rectifier currents, 0-20 NaCl, 0-2 $\mathrm{MgSO}_{4}$, 50 HEPES, 0.1-5 EGTA, 50-250 KCl, 250-350 NMG, 5 MgATP, $1 \mathrm{Na}_{2} \mathrm{GTP}$, and 10 reduced glutathione, $\mathrm{pH}$ 7.4 (with $\mathrm{HCl}$ ).

Voltage clamp in the whole-cell configuration (Hamill et al., 1981) was used to measure the inward rectifier and $\mathrm{Ca}^{2+}$ currents using the Axopatch 200A amplifier (Axon Instruments, Foster City, CA). Recording pipettes were pulled and fire-polished with a horizontal Flaming-Brown microelectrode puller (Sutter Instrument Company, San Rafael, CA). To reduce the pipette capacitance, we coated regions close to the tip of the pipette with Sylgard 184 (Dow Coring, Midland, MI). Pipettes had a final resistance of 0.7-1.6 M $\Omega$. Series resistance (1.2-4.5 M 2 ) was compensated (nominally $50-60 \%$ ). Records were filtered at $5 \mathrm{kHz}$ with a low-pass Bessel filter and were digitized at $10 \mathrm{kHz}$ with a Digidata interface controlled by the pClamp software version 5.7.1 (Axon Instruments). Data were stored on a personal computer (Gateway, Sioux City, $\mathrm{SD})$. Leakage current was canceled on-line with the $\mathrm{p} /-5$ protocol. Cell capacitance was measured as described (Yamoah et al., 1994). After the capacitance of the electrode had been canceled electronically, cells were held at $-60 \mathrm{mV}$ and stepped to $-80 \mathrm{mV}(\Delta \mathrm{V}=20 \mathrm{mV})$. The time constant of relaxation and the area above the transient that represents the charge $(Q)$ were measured. The capacitance $\left(C_{m}\right)$ was calculated from the equation $C_{m}=Q / \Delta \mathrm{V}$. Analyses of the data were performed using Clampfit (Axon Instruments), Sigma plot (Jandel Scientific, San Rafael, CA), and Microcal Origin (Microcal Software, Northampton, $\mathrm{MA}$ ) programs. Values are expressed as mean \pm SD.

Intracellular recording. Isolated nervous systems were incubated in a protease solution (P-8038, $2 \mathrm{mg} / \mathrm{ml}$ in ASW; Sigma) at room temperature for $7 \mathrm{~min}$ to facilitate microelectrode penetration. Photoreceptors were impaled using 30-45 $\mathrm{M} \Omega$ microelectrodes filled with potassium acetate. Current-clamp experiments were accomplished via an Axoclamp 2A (Axon Instruments). Data were fed into a tape recorder and later digitized at $1 \mathrm{kHz}$ or obtained as recordings from a Gould Brush recorder.

\section{RESULTS}

We investigated the membrane properties of Hermissenda photoreceptors to understand the underlying mechanisms for spontaneous activity and the response of type $\mathrm{A}$ and $\mathrm{B}$ photoreceptors to light and darkness. The kinetic and pharmacological properties of a low-voltage activated transient calcium current $\left(I_{\mathrm{Cat}}\right)$ and two inward rectifier currents were examined in both cell types. Type A and B cells expressed $I_{\text {Cat }}$ at similar densities. Two types of inward rectifier currents are described from both type A and B cells, time-dependent and time-independent currents. Both cell types expressed the two currents, but the A cells predominantly expressed the time-independent current ( $\sim 90 \%)$, whereas the B cells exhibited the time-dependent current $(\sim 77 \%)$.

\section{Light response and dark adaptation of photoreceptors}

Figure 1 illustrates the basic differences in the electrical properties of type A and B photoreceptors. Figure 1 (top) shows the light response of a typical type A cell during a $5 \mathrm{sec}$ light pulse. The A cells are relatively hyperpolarized at rest compared with type B cells (Alkon and Fuortes, 1972) and are quiescent after dark adaptation. In contrast, as shown in Figure 1 (bottom), B cells are tonically active even after dark adaptation. Inspection of the records in Figure 1 suggests that type A and B photoreceptors 

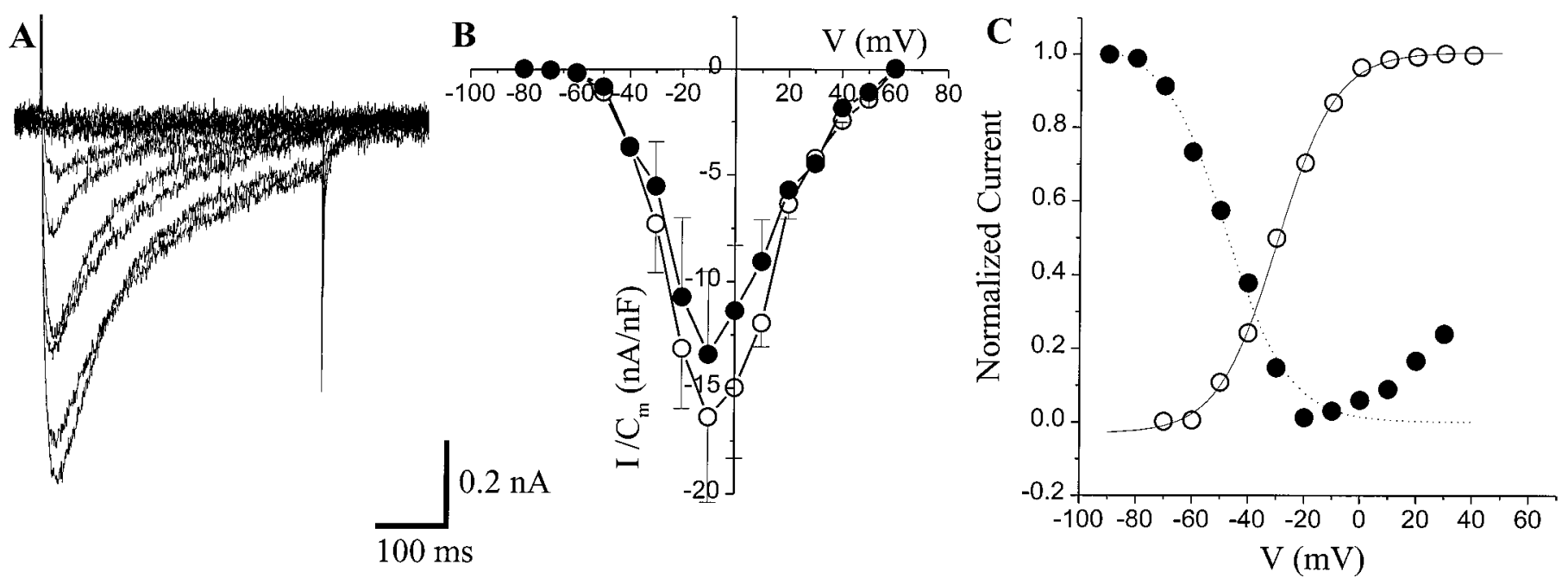

$\mathbf{D}$

E
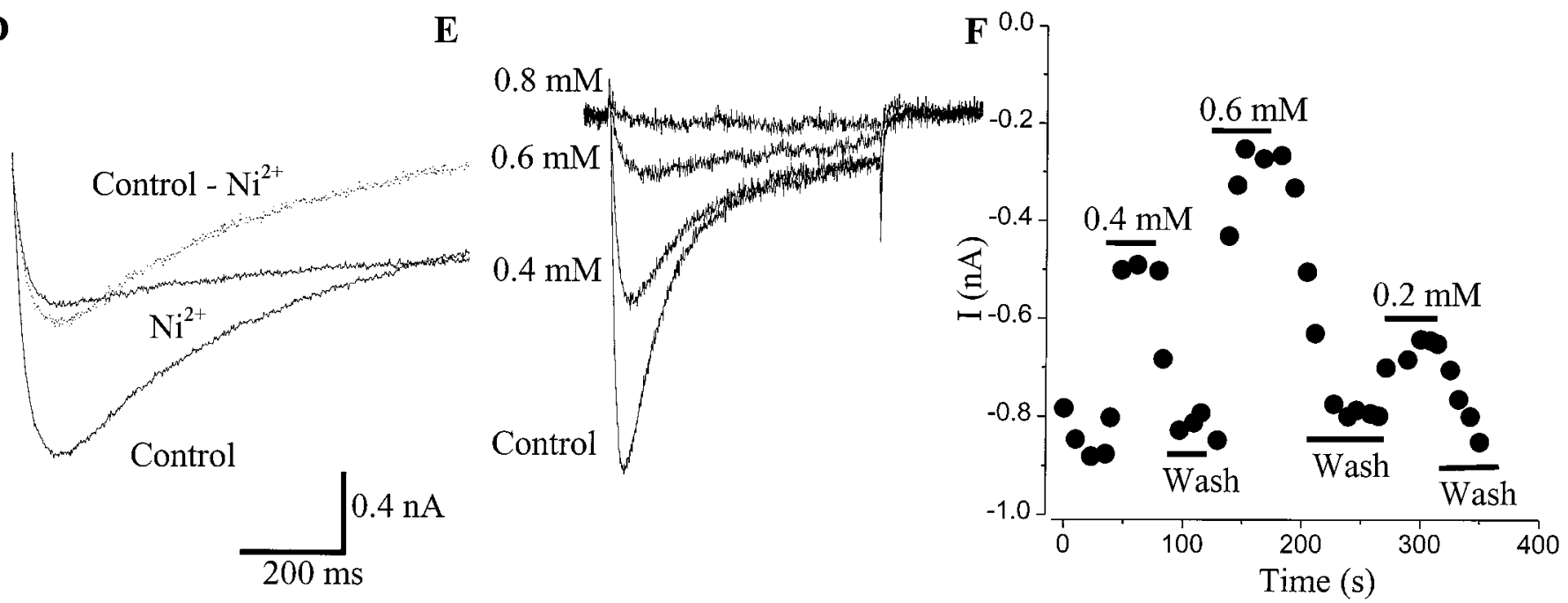

Figure 2. Transient $\mathrm{Ca}^{2+}$ current. $A$, Examples of transient $\mathrm{Ca}^{2+}$ current traces generated by depolarizing voltage steps in a $\mathrm{B}$ cell in ASW with $10 \mathrm{mM} \mathrm{Ca}^{2+}$ are shown. Voltage steps were delivered from the holding potential of $-90 \mathrm{mV}$ to potentials ranging from -80 to $60 \mathrm{mV}$ in $10 \mathrm{mV}$ increments. Some traces have been removed for clarity. $B$, The $I-V$ relations of current densities plotted as a function of voltage from type A ( ) and B (O) cells are shown. Cell capacitance was measured as described in Materials and Methods. $C$, In a type B cell that predominantly expressed the transient $\mathrm{Ca}^{2+}$ current, steady-state activation $(O)$ and inactivation $(\bullet)$ curves were generated and fitted to a Boltzmann function. The fits are plotted with solid and dotted lines. Half-activation and inactivation (assuming complete voltage-dependent inactivation) were -40 and $-48 \mathrm{mV}$, respectively. The maximum slopes for the activation and inactivation curves were 10 and $11 \mathrm{mV}$, respectively. Overlap of the steady-state activation and inactivation curves at a voltage range of -60 to $-40 \mathrm{mV}$ suggests that the $\mathrm{Ca}^{2+}$ current is active at the resting potentials of the photoreceptors $(-55$ to $-45 \mathrm{mV}) . D, \mathrm{Ni}^{2+}$ at 0.5 to $2 \mathrm{~mm}$ selectively blocked the transient $\mathrm{Ca}^{2+}$ current. The current traces were elicited from a holding potential of $-90 \mathrm{mV}$ and stepped to $-20 \mathrm{mV}$ from a type A cell. Only the sustained $\mathrm{Ca}^{2+}$ current remained after application of $0.8 \mathrm{~mm} \mathrm{Ni}{ }^{2+}$. The difference current $\left(\mathrm{Ni}^{2+}\right.$-sensitive current; trace shown with dotted line $)$ is the transient component. $E$, Changes in the transient $\mathrm{Ca}^{2+}$ current magnitude as $\left[\mathrm{Ni}^{2+}\right]$ was gradually increased from 0 to $0.8 \mathrm{~mm}$ are shown. $F$, The effect of $\mathrm{Ni}^{2+}$ was reversible after washout. The time course and the effect of different concentrations of $\mathrm{Ni}^{2+}$ on the transient $\mathrm{Ca}^{2+}$ current are shown.

differ both in their tonic and phasic responses to light. We speculated that the inward currents expressed by the two cell types may differ, rendering the B cells spontaneously active while the A cells remain electrically silent after dark adaptation. Three inward currents were found to be crucial for the dark-response properties of the A and B cells.

\section{Transient calcium current}

Transient low-voltage activated $\mathrm{Ca}^{2+}$ currents have been reported to contribute to the initial depolarization phase of action potentials (Llinas and Yarom, 1981). The transient $\mathrm{Ca}^{2+}$ current in the soma of the photoreceptors has been studied previously (Yamoah and
Crow, 1994), but the functions of the current are unknown. Experiments were performed in solutions expected to suppress all ionic currents except $\mathrm{Ca}^{2+}$ currents (see Materials and Methods). Shown in Figure $2 A$ are representative traces of the transient component of the $\mathrm{Ca}^{2+}$ current recorded from a type $\mathrm{B}$ cell at a holding potential of $-90 \mathrm{mV}$. Data of the current density plot from types A and B cells are represented in Figure $2 B$. In both cell types, the current was activated at potentials close to $-50 \mathrm{mV}$ and peaked at approximately -10 to $0 \mathrm{mV}$. There were no significant differences between the two cell types in the current densities at all recorded step potentials. The examples shown represent cells that predominantly express the transient component of the $\mathrm{Ca}^{2+}$ cur- 
A

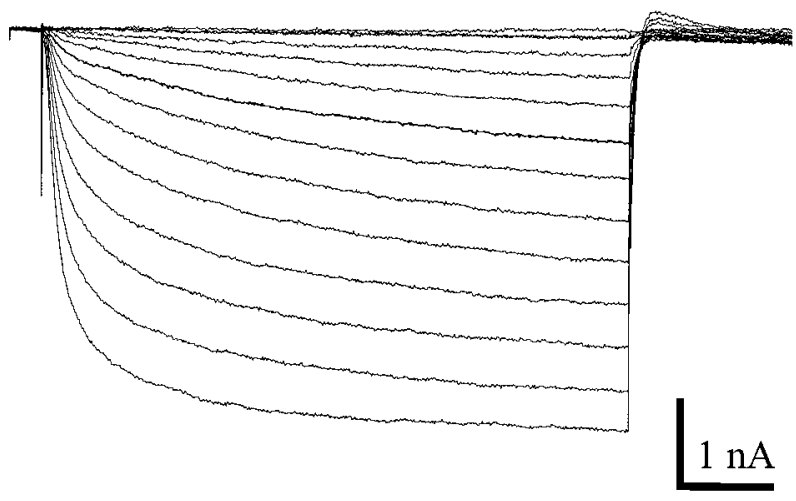

C

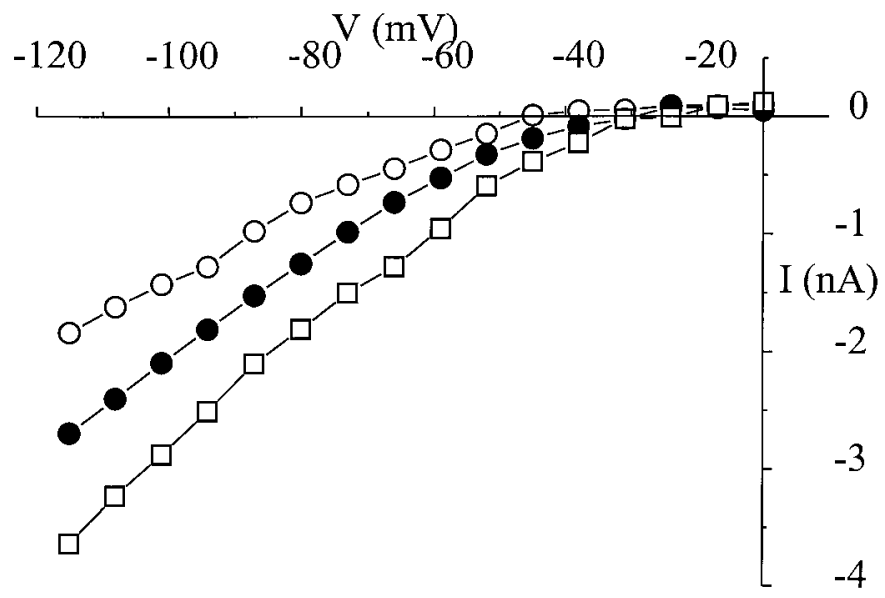

B

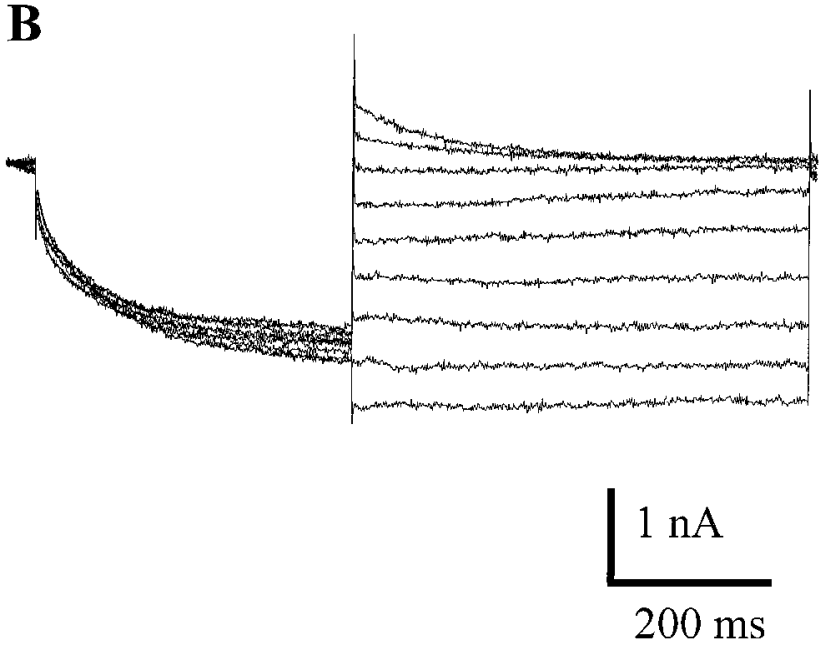

D

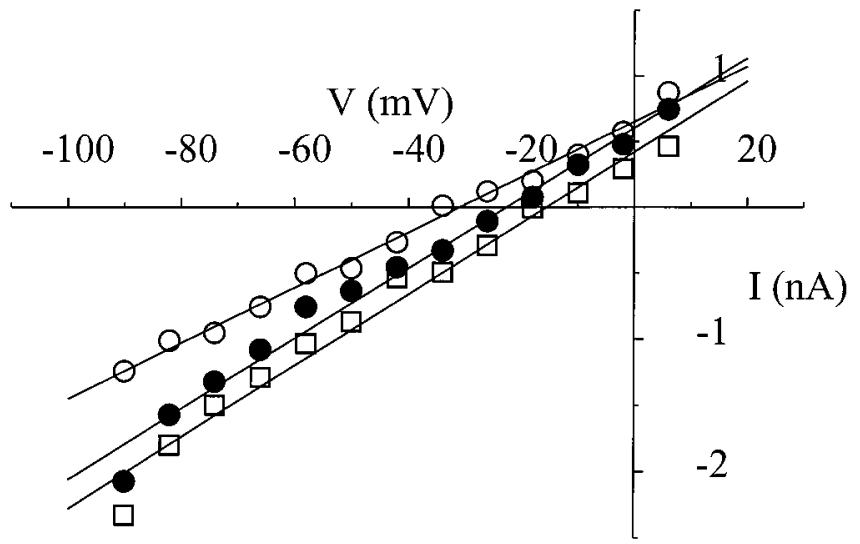

Figure 3. Time-dependent inward rectifier current $\left(I_{h}\right)$. A, A type B photoreceptor was held at $-45 \mathrm{mV}$ and stepped to positive and negative voltages relative to the holding potential $(\Delta \mathrm{V}=7 \mathrm{mV})$. A time-dependent inward current that exhibited rectification at potentials positive to the apparent reversal potential was elicited. Traces shown were collected from an average of five runs. $B$, Shown as well are tail current traces from the same cell. $C$, The corresponding $I-V$ plot is shown. An apparent reversal potential of $-36 \mathrm{mV}$ was calculated from the regression line generated from instantaneous current traces $(\bigcirc)$. Alteration of external $\mathrm{K}^{+}$concentration $\left(\left[\mathrm{K}^{+}\right]_{\mathrm{o}}\right)$ shifted the apparent reversal potential of $I_{h}$. Pipette $\left[\mathrm{K}^{+}\right]_{\mathrm{i}}$ was $250 \mathrm{mM}$, and the altered $\left[\mathrm{K}^{+}\right]_{\mathrm{o}}$ was $2.5,10$, or $30 \mathrm{~mm}$, shown on the corresponding $I-V$ plots as $\bigcirc, \boldsymbol{\bullet}$, or $\square$, respectively. $D$, Changes in $\left[\mathrm{Na}^{+}\right]_{\mathrm{o}}$ also altered the apparent reversal potential $\left(E_{\mathrm{rev}}\right)$ of $I_{h}$. Alteration of $E_{\mathrm{rev}}$ by changing $\left[\mathrm{Na}^{+}\right]_{\mathrm{o}}$ suggested that the $I_{h}$ channel is permeable to $\mathrm{Na}^{+}$as well. Shown are representative plots of the instantaneous $I-V$ relationship generated from tail current records with varying $\left[\mathrm{Na}^{+}\right]_{\mathrm{o}}$. The $\left[\mathrm{Na}^{+}\right]_{\mathrm{o}}$, the corresponding $E_{\text {rev }}$, and the conductances are $20 \mathrm{mM},-30.9 \mathrm{mV}, 21.1 \mathrm{nS} ; 70 \mathrm{mM},-22.8 \mathrm{mV}, 22.8 \mathrm{nS}$; and $100 \mathrm{~mm},-15.6 \mathrm{mV}, 27.0 \mathrm{nS}$, shown as $\bigcirc$, $\bullet$, and $\square$, respectively. Using the Goldman-Hodgkin-Katz equation (Hille, 1992), the permeability ratio for $\mathrm{K}^{+}$versus $\mathrm{Na}^{+}\left(P_{\mathrm{K}} / P_{\mathrm{Na}}\right)=0.7$ for this channel.

rent. Typically, we isolated the transient current by suppressing the sustained $\mathrm{Ca}^{2+}$ current with bath application of nitrendipine (5 $\mu \mathrm{M})$ (Yamoah and Crow, 1994). Steady-state activation and inactivation of $I_{\text {Cat }}$ revealed a window current close to the resting potential of the photoreceptors ( -60 to $-40 \mathrm{mV}$ ) (Fig. 2C). A previous report showed that both type $\mathrm{A}$ and $\mathrm{B}$ cells express sustained and transient $\mathrm{Ca}^{2+}$ currents (Yamoah and Crow, 1994, 1996). In an A cell in which both $\mathrm{Ca}^{2+}$ current subtypes were expressed, $\mathrm{Ni}^{2+}$ blocked the transient component but left the sustained current unblocked (Fig. 2D). Typical traces of the effects of $\mathrm{Ni}^{2+}$ on $I_{\text {Cat }}$ in an A cell are shown in Figure $2 E$. The records show that the transient $\mathrm{Ca}^{2+}$ current was reduced by $\mathrm{Ni}^{2+}$ in a concentration-dependent manner with a half-blocking concentration of $0.4 \pm 0.21 \mathrm{~mm}(n=6)$. The time course and the concentration dependence of the blocking action of $\mathrm{Ni}^{2+}$ on the transient current are demonstrated in Figure $2 F$. The effect of $\mathrm{Ni}^{2+}$ was reversed after $\sim 50 \mathrm{sec}$ of washout.

\section{Time-dependent inward rectifier current}

In Figure $3 A$ are representative traces of a time-dependent, hyperpolarization-activated current recorded from a type B cell with a holding potential of $-45 \mathrm{mV}$. A previous report of inward rectification in the photoreceptors identified the current as $I_{\mathrm{ir}}$ (Acosta-Urquidi and Crow, 1993). In the initial report, only one form of inward rectification in the B photoreceptors was examined. As shown below, there are two distinct types of inward rectification in type $\mathrm{A}$ and $\mathrm{B}$ cells. Because of the similarities of the inward rectifier current in the B cells to the time-dependent hyperpolarization-activated currents in photoreceptors (Hestrin, 1987) and other systems (Angstadt and Calabrese, 1989; Holt and 

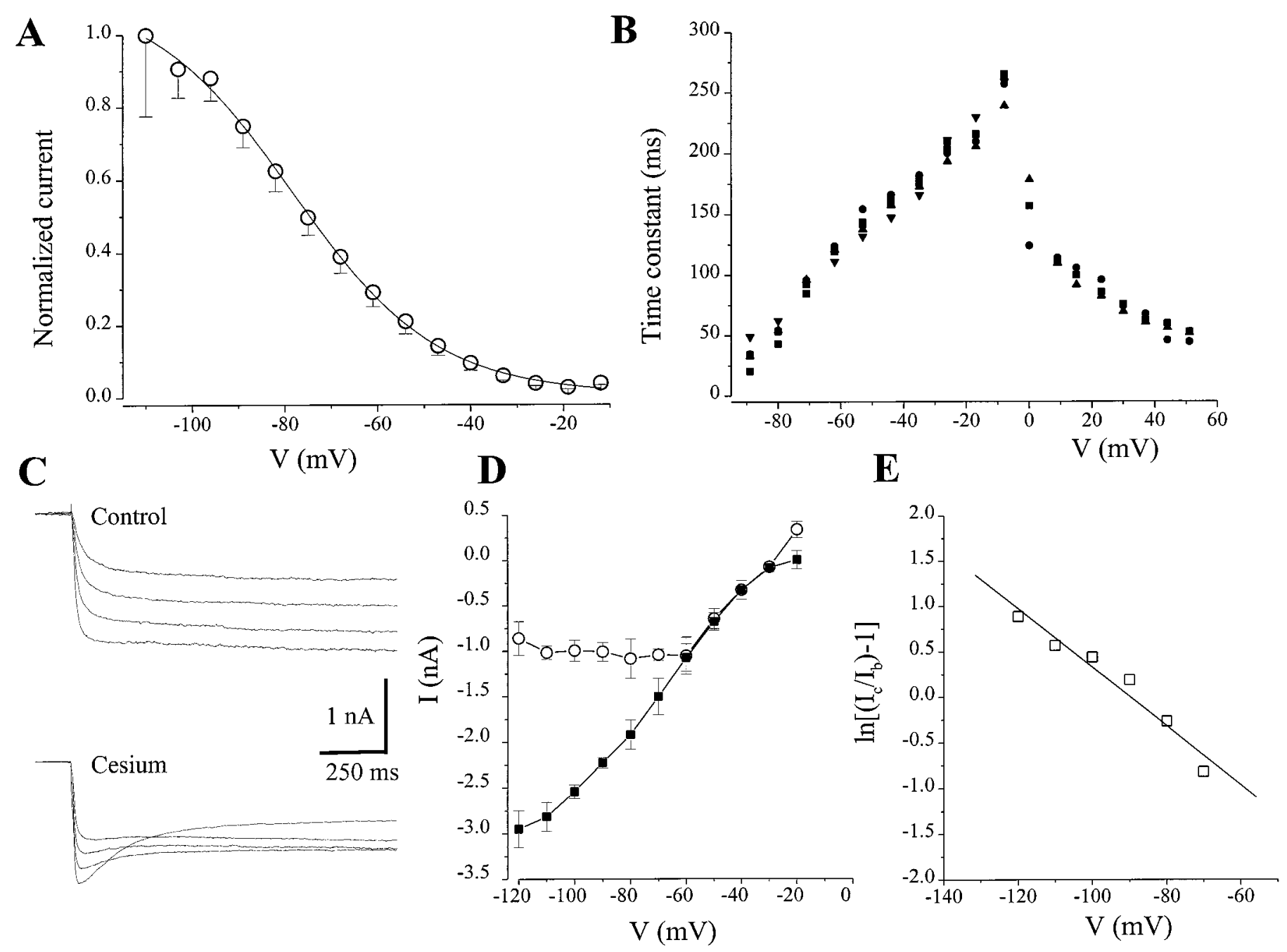

Figure 4. Steady-state activation of $I_{h}$ and the time constant of activation. $A$, The relative current plotted against the step potentials. Error bars represent $\mathrm{SD}(n=9$ cells $)$. The continuous curve was generated from the Boltzmann function $\left(I / I_{\max }=\left[1+\exp \left(\mathrm{V}_{1 / 2}-\mathrm{V}\right) / K_{\mathrm{m}}\right]^{-1}\right)$, where $\mathrm{V}_{1 / 2}$ is the half-activation voltage and $K_{\mathrm{m}}$ is the maximum slope; $\mathrm{V}_{1 / 2}$ of $-73.6 \pm 5.1 \mathrm{mV}$ and $K_{\mathrm{m}}$ of $15.5 \pm 2.3 \mathrm{mV}$ were estimated. $B$, Time constants of activation and deactivation fitted with a single exponential and plotted against the corresponding voltages. Representative data from five cells are plotted with scattered points. $C$, Block of $I_{h}$ by Cs ${ }^{+}$. The time-dependent inward rectifier current was blocked in the presence of $0.5 \mathrm{mM} \mathrm{Cs}^{+}$. $\mathrm{Cs}^{+}$induced a rapid decay of the current. $D$, Current-voltage relationship of control $(\mathbf{\square})$ and after application of $0.5 \mathrm{mM} \mathrm{Cs}^{+}(\bigcirc)\left(n=6\right.$ type B cells). In the presence of $2 \mathrm{~mm} \mathrm{Cs}{ }^{+}$, most of the inward-rectifying currents were blocked; however, there remained a time-independent current (data not shown). In five type B cells with a peak current of $-1.95 \pm 0.98 \mathrm{nA}$, the remaining time-independent peak current after application of $2 \mathrm{~mm} \mathrm{Cs}{ }^{+}$was $-0.20 \pm 0.14 \mathrm{nA}$. Therefore it is estimated that only $10 \%$ of inward rectification in the type B cells is time-independent. $E$, Estimation of the binding site for $\mathrm{Cs}^{+}$. The voltage dependence of Cs ${ }^{+}$ blockade of the pore was determined assuming a binding model as described previously (Woodhull, 1973). The model assumes a single site for Cs ${ }^{+}$ binding whose availability but not intrinsic affinity changes with voltage. $\mathrm{Cs}^{+}$is assumed to be an impermeant blocker that enters and exits the pore from the same side. A linear transformation of the voltage dependence of the ratio of the unblocked current (peak current amplitude) and blocked current (steady-state current amplitude) is as follows: $\ln \left\{\left(I_{c} / I_{b}\right)-1\right\}=\ln \left(K_{A}\right) \times\left[\mathrm{Cs}^{+}\right]-\delta(Z e \mathrm{~V} / R T)$, where $I_{c}$ is the unblocked and $I_{b}$ is the blocked macroscopic current amplitudes, $K_{A}$ is the association constant, $\delta$ is the fractional electrical distance from the outer face of the membrane, and $Z, e, R$, and $T$ have their usual meanings. The slope of the linear plot gives the $\delta$. The data were fit by least squares linear regression. The calculated membrane electric field $(\mathrm{z} \delta)$ sensed by $\mathrm{Cs}^{+}$from the linear plot was 0.8 .

Eatock, 1995), the current will be denoted $I_{h}$. Tail current traces from the same cell are shown (Fig. 3B). The current-voltage relationship is shown in Figure $3 C$. The permeation property of the channel was assessed by alteration of bath $\left[\mathrm{K}^{+}\right],\left[\mathrm{Na}^{+}\right]$, and $\left[\mathrm{Cl}^{-}\right]$. Alteration of bath or pipette $\left[\mathrm{K}^{+}\right]$shifted the reversal potential $\left(E_{\mathrm{rev}}\right)$ of the current (Fig. $\left.3 C\right)$. An increase in bath $\left[\mathrm{Na}^{+}\right]$shifted the $E_{\mathrm{rev}}$ to more positive voltages, whereas the reverse was the case when $\left[\mathrm{Na}^{+}\right]$was reduced (Fig. $3 D$ ). In contrast, changes in $\left[\mathrm{Cl}^{-}\right]$did not alter the $E_{\text {rev }}$ of the current. A small but significant $\mathrm{Cl}^{-}$current is present in the photoreceptors (Yamoah and Kuzirian, 1994); however, this current is predom- inantly outward rectifying. Therefore, $\mathrm{Cl}^{-}$current contributes very little to the total inward-rectifying current in the photoreceptors.

Activation of the current was voltage- and time-dependent. A normalized, steady-state activation curve for $I_{h}$ is presented in Figure $4 A$. The Boltzmann distribution fit for the curve had a half-activation voltage $\left(\mathrm{V}_{1 / 2}\right)$ of $-74 \pm 5 \mathrm{mV}$ and a maximum slope $\left(K_{\mathrm{m}}\right)$ of $15.5 \pm 2.3 \mathrm{mV}(n=9)$. A single time constant provided a best fit for the activation and deactivation profiles of the current. A plot of the time constants of activation and deactivation versus membrane potentials is shown in Figure $4 B$. 


\section{A}

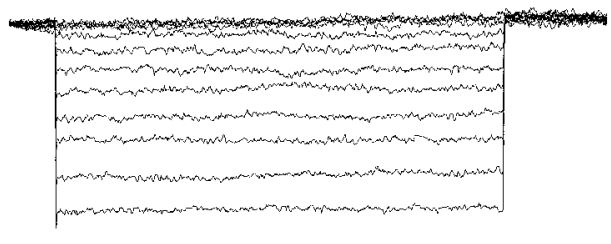

B

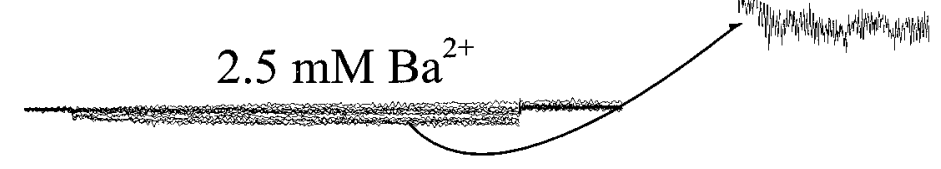

$0.5 \mathrm{nA}$

$100 \mathrm{~ms}$

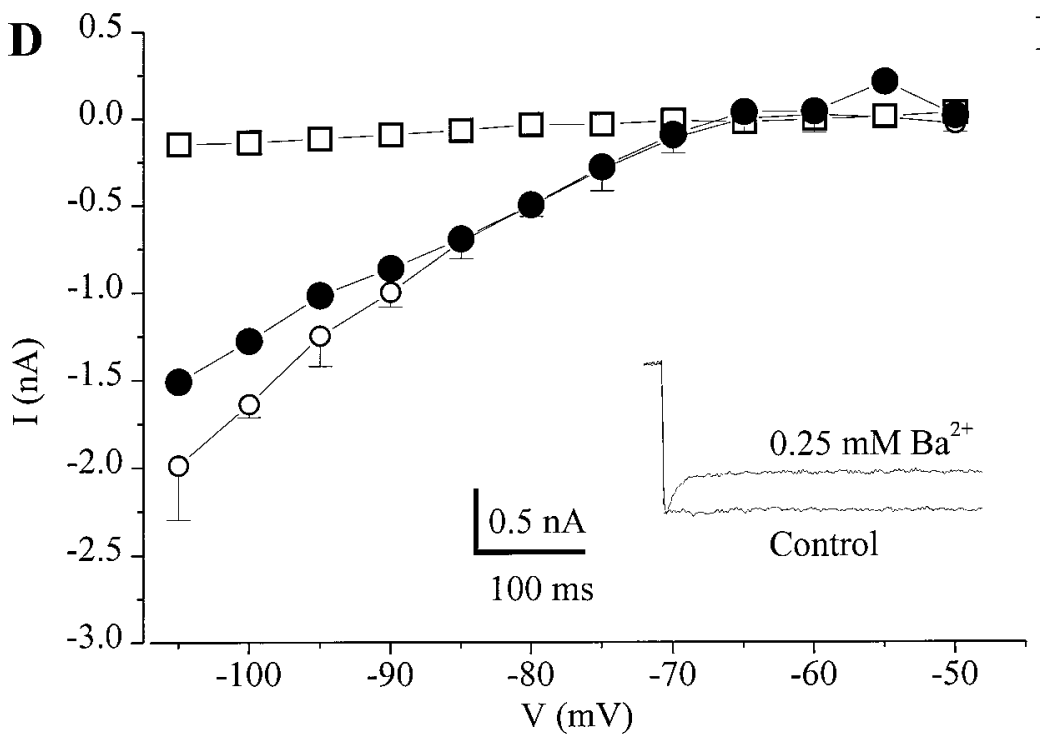

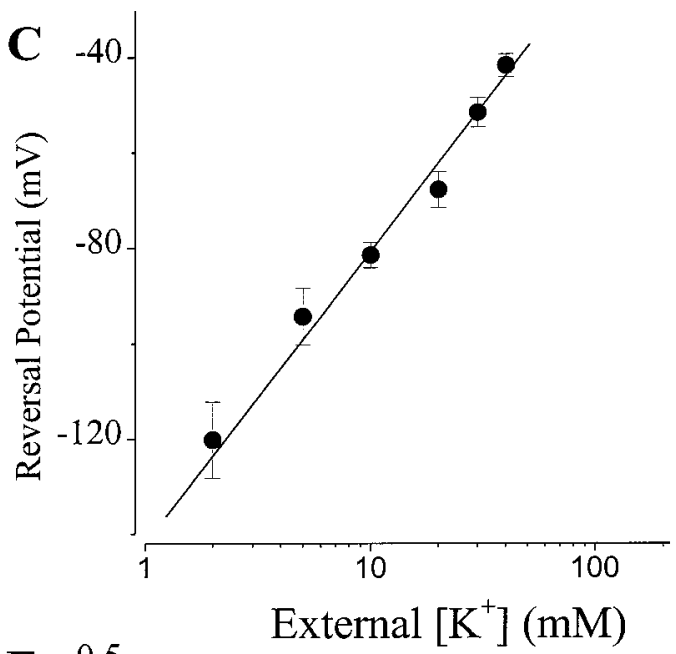

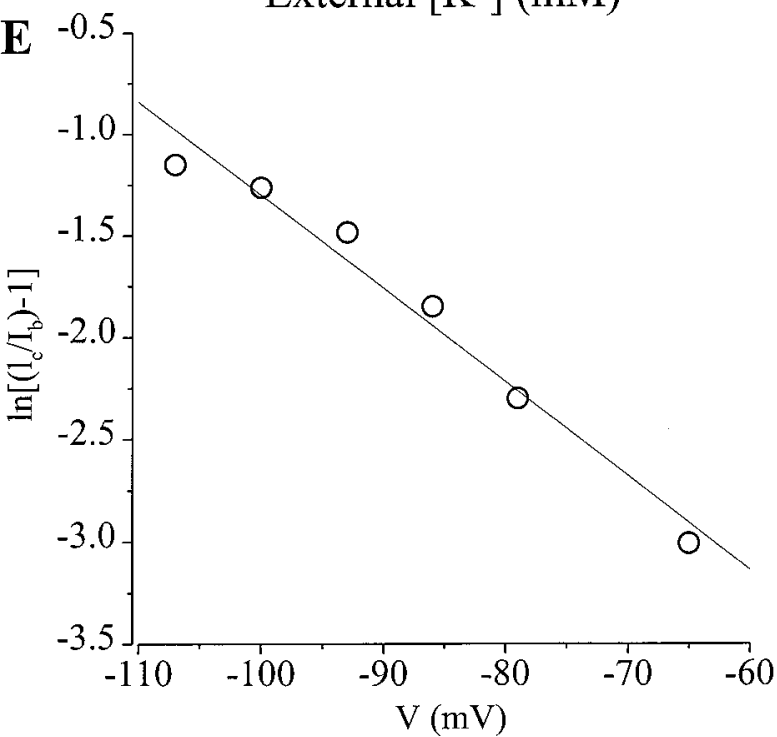

Figure 5. The inward rectifier current in type A photoreceptors was carried by $\mathrm{K}^{+}$. $A$, Type A cells also exhibited inward rectification; however this current was time-independent, and the apparent $E_{\mathrm{rev}}$ was more negative $(-70$ to $-80 \mathrm{mV})$ than were currents recorded from type B cells $(-30$ to -40 $\mathrm{mV}) . B$, This inward rectifier current can be blocked by $\mathrm{Ba}^{2+}$. The remaining current after application of $\mathrm{Ba}^{2+}$ (inset) exhibited a time dependence of activation and can be blocked by $\mathrm{Cs}^{+}$. The effects of $\mathrm{Ba}^{2+}$ were reversible (data not shown). $C$, By varying the external concentration of $\mathrm{K}^{+}$and maintaining a constant pipette $\mathrm{K}^{+}$concentration of $250 \mathrm{~mm}$, we obtained the reversal potentials of the inward rectifier current; these were plotted against the external $\mathrm{K}^{+}$concentration. Data were fit with a linear regression with a slope of $56 \mathrm{mV}$ per $\log$ unit $(r=0.989)$, consistent with a $\mathrm{K}^{+}$-selective pore. $D$, The current-voltage relations of the inward rectifier current at baseline $(\bigcirc ; n=7)$ and after application of $0.25 \mathrm{~mm}(\bullet)$ and $2.5 \mathrm{~mm}(\square) \mathrm{Ba}^{2+}$ are illustrated. This current was more sensitive to block by $\mathrm{Ba}^{2+}$ than by $\mathrm{Cs}^{+}$(data not shown). Cumulative data from six type A cells (control peak current, $1.59 \pm 0.54 \mathrm{nA} ; \mathrm{Ba}^{2+}$-insensitive time-dependent current, $0.35 \pm 0.21 \mathrm{nA}$ ) show that type A cells expressed $\sim 77 \%$ of $I_{\mathrm{K} 1}$ and $23 \%$ of $\mathrm{I}_{\mathrm{h}} . E$, The binding site of $\mathrm{Ba}^{2+}$ within the pore is estimated. The slope yields a $\delta$ of 0.6 from the outer face of the membrane (see Fig. $4 E$ ).

The sensitivity to block of $I_{h}$ by $\mathrm{Cs}^{+}$was tested (Angstadt and Calabrese, 1989; Bond et al., 1994). Cs ${ }^{+}$blocked $I_{h}$ in a voltageand concentration-dependent manner. At large negative pulses, the current turned on rapidly and then decayed with time. This decay became pronounced in the presence of $\mathrm{Cs}^{+}$(Fig. 4C). The current-voltage relationships for control traces and after application of $0.5 \mathrm{~mm} \mathrm{Cs}^{+}$were obtained from six B cells (Fig. 4D). The apparent fraction of the membrane electric field $(\mathrm{z} \delta)$ sensed by $\mathrm{Cs}^{+}$was calculated to be $0.8 \pm 0.1(n=5)$ (Fig. $4 E$; Woodhull, 1973). Sensitivity of the current to $\mathrm{Cs}^{+}$is similar to the inwardly rectifying conductances observed in vertebrate CNS neurons (Yamaguchi et al., 1990), optic nerve, and cone photoreceptors (Eng et al., 1990; Maricq and Korenbrot, 1990), as well as in invertebrate neurons (Angstadt and Calabrese, 1989). However, the hyperpolarization-activated current in Hermissenda photore- ceptors is dissimilar to those reported from retinal glial cells (Newman, 1993), cholinergic neurons in rat brain (Yamaguchi et al., 1990), and Aplysia buccal muscles (Brezina et al., 1994) in that the current showed no sensitivity to $\mathrm{Ba}^{2+}$. In fact, in the presence of $\mathrm{Ba}^{2+}$ or $\mathrm{Ca}^{2+}$, the magnitude of the current increased (data not shown). This may reflect contamination of $I_{h}$ by a background $\mathrm{Ca}^{2+}$ current in the photoreceptors. To avoid the masking effects of a possible hyperpolarizing-activated $\mathrm{Ca}^{2+}$ conductance (Preston et al., 1992), we made recordings of $I_{h}$ at reduced $\left[\mathrm{Ca}^{2+}\right]$ (see Materials and Methods).

\section{Time-independent inward rectifier current}

Type A cells expressed a time-dependent and time-independent inwardly rectifying current. However, the time-independent current was predominant $(\sim 77 \% ; n=6$; Fig. 5$)$ in the A cells. We 

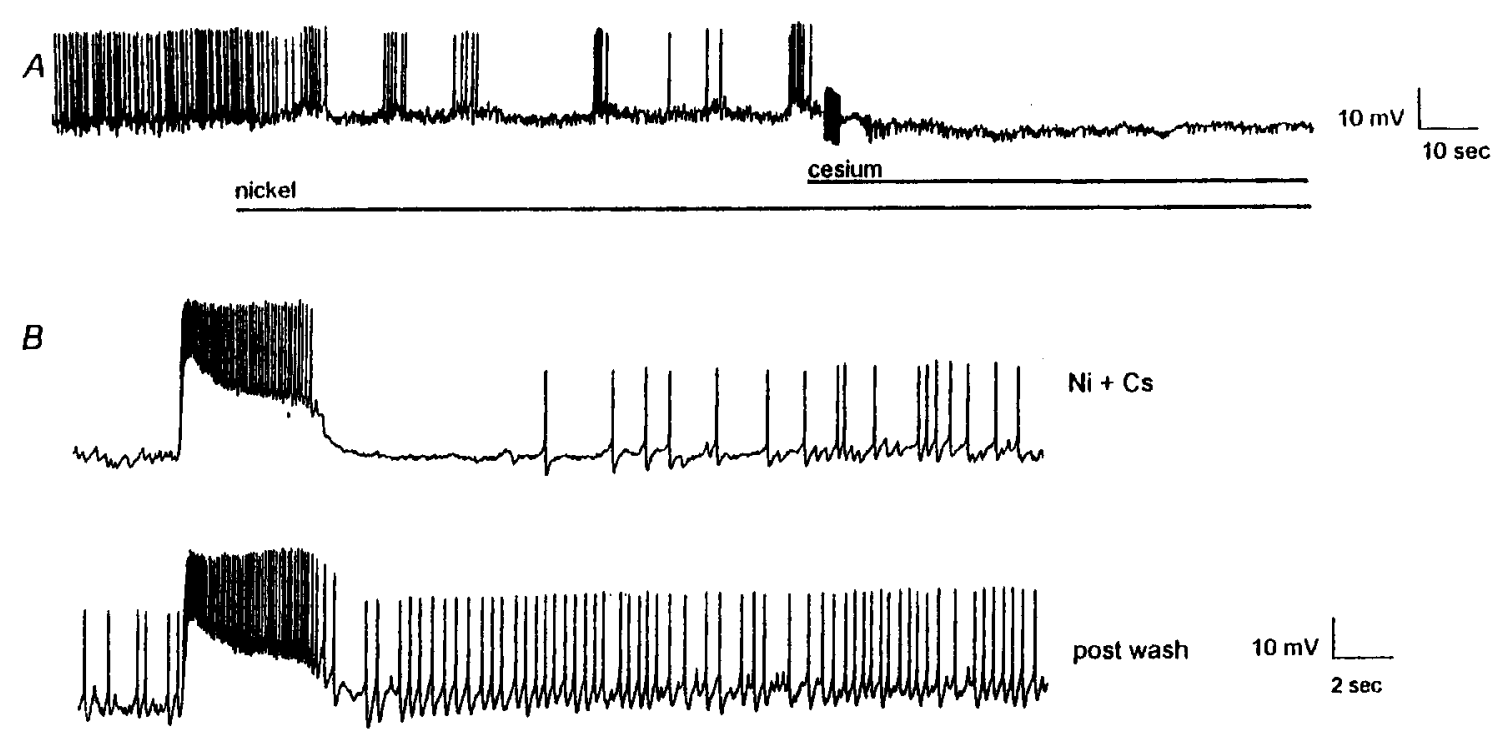

$C$

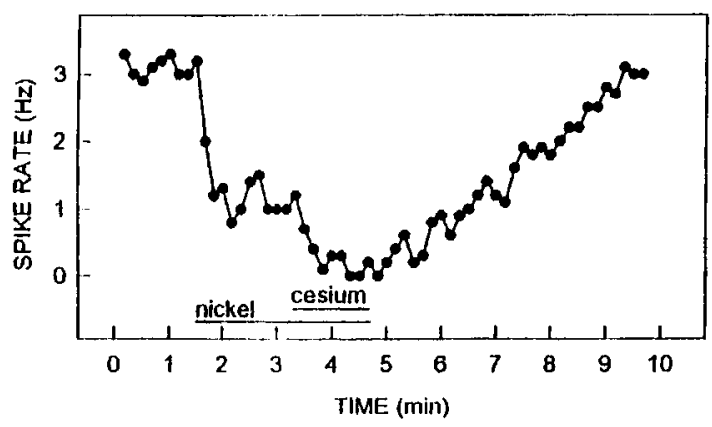

$D$

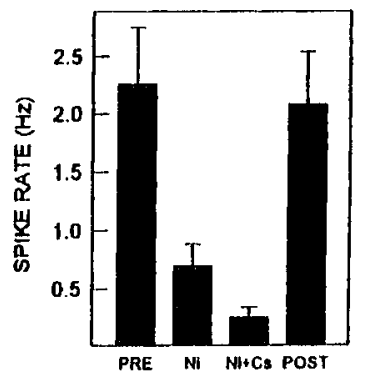

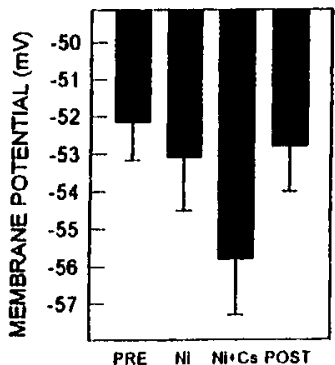

Figure 6. Pharmacological manipulation of the electrical activity of type $\mathrm{B}$ cells with $\mathrm{Ni}^{2+}$ and $\mathrm{Cs}^{+} . A$, The characteristic tonic activity of $\mathrm{B}$ cells in control solutions is transformed into alternating burst activity after bath perfusion with $1.5 \mathrm{mM} \mathrm{Ni}^{2+}$-containing artificial seawater. Addition of 2 mM $\mathrm{Cs}^{+}$to the $\mathrm{Ni}^{2+}$ solution completely abolished spontaneous activity of the $\mathrm{B}$ cell in dark-adapted conditions. B, Top, Light-elicited generator potential and the corresponding spike rate in the predark-adapted stage were reduced in the presence of $\mathrm{Ni}^{2+}$ and $\mathrm{Cs}^{+}$. Bottom, $\mathrm{Replacement}^{2}$ of $\mathrm{Ni}^{2+}-$ and $\mathrm{Cs}^{+}$-containing solution with normal artificial seawater restored the excitability of the $\mathrm{B}$ cells. $C$, In the cell shown in $B, \mathrm{Ni}^{2+}$ decreased the spike rate from $\sim 3$ to $1 \mathrm{~Hz} ; \mathrm{Cs}^{+}$reduced the spike rate further to $0 \mathrm{~Hz}$. $D$, Data from five cells on the effects of $\mathrm{Ni}^{2+}$ and $\mathrm{Cs}^{+}$on spike rate and membrane potential are shown.

refer to the time-independent inward rectifier current as $I_{\mathrm{K} 1}$, consistent with the terminology used for a similar current in cardiac cells (Kurachi, 1985). Figure 5A shows current traces recorded in a type A cell superfused with a $\mathrm{Na}^{+}$-free recording solution during hyperpolarizing voltage steps from the $-50 \mathrm{mV}$ holding potential. Hyperpolarization to potentials more negative than $-70 \mathrm{mV}$ induced an inward current. The current activated rapidly and exhibited little or no decay. As the bath $\left[\mathrm{K}^{+}\right]_{\mathrm{o}}$ was increased, the reversal potential of the current shifted to more positive potentials, in a manner predicted by the Nernst potential for a $\mathrm{K}^{+}$-selective conductance (Fig. 5 C). Raising $\left[\mathrm{K}^{+}\right]_{\mathrm{o}}$ resulted in a steeper slope conductance as well and produced a shift in the activation voltage range of the current in the positive direction (data not shown). In contrast to $I_{h}, I_{\mathrm{K} 1}$ was blocked by $\mathrm{Ba}^{2+}$ (Fig. $5 A, B) . \mathrm{Ba}^{2+}$ produced a voltage-dependent block of $I_{\mathrm{K} 1}$, and the fractional electrical distance between the external orifice of the channels and the $\mathrm{Ba}^{2+}$ binding site was calculated to be $0.6 \pm 0.1$ $(n=4$ : see Fig. $5 D, E)$. Application of $\mathrm{Na}^{+}$-containing solution induced an apparent inactivation of the current that is reminiscent of the extracellular $\mathrm{Na}^{+}$block of inward rectifier currents observed in tunicate egg cells (Ohmori, 1978), skeletal muscles
(Standen and Stanfield, 1979), and endothelial cells (Silver and DeCoursey, 1990).

\section{Effects of $\mathrm{Cs}^{+}, \mathrm{Ba}^{2+}$, and $\mathrm{Ni}^{2+}$ on the excitability of $\mathrm{A}$ and $B$ cells}

Alkon (1979) reported that $\mathrm{Ni}^{2+}$ altered spontaneous activity of $\mathrm{B}$ photoreceptors. Although the mechanisms for the effects of $\mathrm{Ni}^{2+}$ were not investigated, it is possible that $\mathrm{Ni}^{2+}$ block of the $I_{\text {Cat }}$ may be the underlying mechanism for $\mathrm{Ni}^{2+}$-induced alteration of spontaneous activity of the B cells. It has been suggested that inward rectification is responsible for a voltage "sag" observed in the B cells after the injection of hyperpolarizing currents (Acosta-Urquidi and Crow, 1995). The voltage sag is followed by a rebound spike activity. A combination of the inward currents may partly explain the differences in the properties of $\mathrm{A}$ and $\mathrm{B}$ photoreceptors. This idea was examined further by blocking the transient $\mathrm{Ca}^{2+}$ and inward rectifier currents with bath application of $\mathrm{Ni}^{2+}, \mathrm{Cs}^{+}$, and $\mathrm{Ba}^{2+}$.

To account for diffusional barriers in intact preparations, we applied relatively high concentrations of the blockers. Figure 6 illustrates the effects of $\mathrm{Ni}^{2+}$ and $\mathrm{Cs}^{+}$on type $\mathrm{B}$ cells. Block of 
$A$

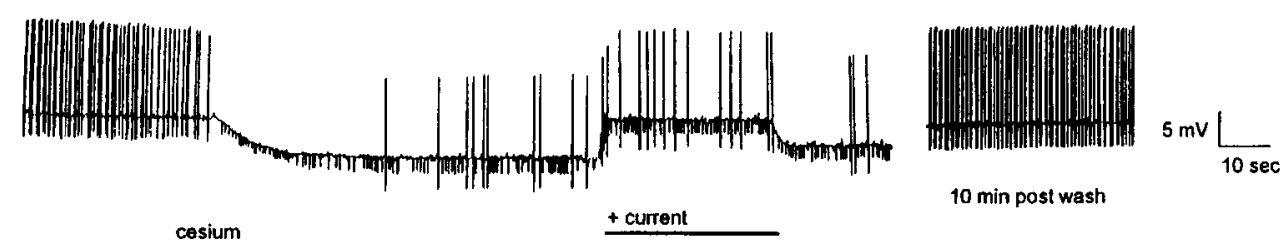

$B$

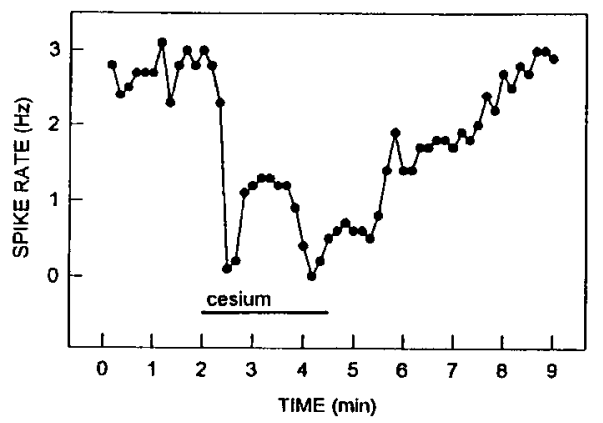

$c$

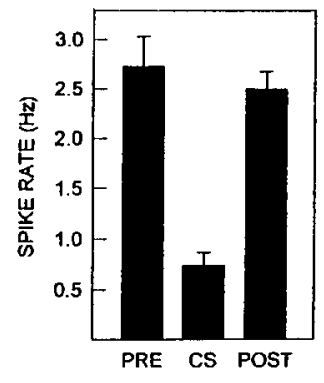

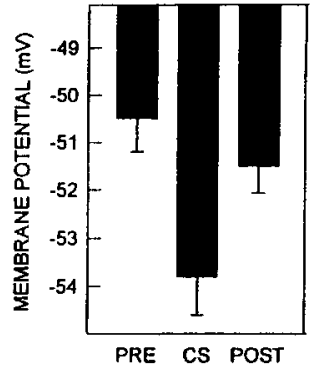

Figure 7. Effects of $\mathrm{Cs}^{+}$on the membrane properties of type B photoreceptors. $A$, Spontaneous activity of B photoreceptors in normal artificial seawater consists of uninterrupted burst spikes in type B photoreceptors in the dark. After application of $2 \mathrm{~mm} \mathrm{Cs}{ }^{+}$, the steady-state potential dropped to a more hyperpolarized potential, and the spike rate was reduced. Injection of positive current to depolarize the steady-state potential close to control conditions was insufficient to restore the spike rate. However, after $10 \mathrm{~min}$ of washout, the spike rate returned to control levels. $B$, In the B cell shown in $A, \mathrm{Cs}^{+}$induced a spike rate of $\sim 0.5 \mathrm{~Hz}$ compared with a rate in controls of $2.5 \mathrm{~Hz}$. $C$, Cumulative data from five type $\mathrm{B}$ cells are shown. Cs ${ }^{+}$reduced the spike rate from $2.7 \pm 0.5$ to $0.7 \pm 0.3 \mathrm{~Hz}$. However, the spike rate returned to $2.5 \pm 0.4 \mathrm{~Hz}$ that was not significantly different from control after washout.

the transient $\mathrm{Ca}^{2+}$ current by $\mathrm{Ni}^{2+}$ induced a burst pattern that was characteristically phasic, unlike the nonphasic, spontaneous activity of the $\mathrm{B}$ cells in vivo. In Figure $6 A, 1.5 \mathrm{~mm} \mathrm{Ni}^{2+}$ reduced the frequency of spontaneous activity. Spontaneous activity of the photoreceptors was reduced further after the application of $2 \mathrm{~mm}$ $\mathrm{Cs}^{+}$. Both $\mathrm{Ni}^{2+}$ and $\mathrm{Cs}^{+}$reduced the spontaneous firing of the type $\mathrm{B}$ cells (Fig. $6 B-D$ ). $\mathrm{Cs}^{+}$alone induced membrane hyperpolarization and reduced the rate of firing of B cells (Fig. 7). We further illustrate that membrane depolarization by current injection was insufficient to increase the firing rate, after block of $I_{h}$ by $\mathrm{Cs}^{+}$. The effects of $\mathrm{Cs}^{+}$were reversible after washout.

Type A and B cells have similar spike rates in response to light $(\sim 40 \mathrm{~Hz})$, but the two cell types are dissimilar in their darkresponse properties (Fig. 8). The B cells remain tonically active with a spike rate of $\sim 3 \mathrm{~Hz}$ in darkness, whereas the A cells remain quiet after termination of light stimuli (Fig. 8). $\mathrm{Ba}^{2+}$, a specific blocker of $I_{\mathrm{K} 1}$, significantly increased the spontaneous activity of A cells in darkness [spike frequency in the dark, $0.2 \pm$ $0.2 \mathrm{~Hz}$ (mean $\pm \mathrm{SD})$; spike frequency in darkness in the presence of $\mathrm{Ba}^{2+}, 2.2 \pm 1.1 \mathrm{~Hz}$ (mean $\left.\left.\pm \mathrm{SD}\right) ; n=5 ; p<0.005\right]$ but failed to produce substantial changes in the light-elicited spike activity in type A and B cells (see Fig. 8B). In contrast to the activity in type A cells, the tonic activity of type B cells in darkness was not significantly altered by $\mathrm{Ba}^{2+}$ (spike frequency of $\mathrm{B}$ cells in the dark, $2.5 \pm 0.6 \mathrm{~Hz}$; spike frequency in darkness in the presence of $\mathrm{Ba}^{2+}, 2.6 \pm 0.6 \mathrm{~Hz} ; n=5 ; p=0.8$, not significant).

\section{DISCUSSION}

The properties of a transient $\mathrm{Ca}^{2+}$ and two distinct inward rectifier currents in the photoreceptors of Hermissenda were studied to understand the underlying mechanisms for the electrophysiological differences between type A and B photorecep- tors. Here, we report the following. (1) A transient $\mathrm{Ca}^{2+}$ current is expressed in both cells at similar densities, and this current contributes to the generation of action potentials in both cell types. (2) Both type A and B photoreceptors express two inward rectifier currents, a time-dependent $\left(I_{h}\right)$ current and a timeindependent $\left(I_{\mathrm{K} 1}\right)$ current. However, $I_{\mathrm{K} 1}$ is predominantly expressed by the type A cells. (3) In contrast, type B photoreceptors express mainly $I_{h}$ that has kinetic and pharmacological properties that are distinct from $I_{\mathrm{K} 1}$. (4) $I_{\mathrm{K} 1}$ contributes to membrane hyperpolarization and controls the resting membrane potential of cells during dark adaptation, whereas $I_{h}$ enhances membrane depolarization and promotes the spontaneous firing properties of the cells in the dark. The additive properties of the $\mathrm{Ca}^{2+}$ current and $I_{h}$ induce spontaneous activity in the B cells. However, the predominant expression of $I_{\mathrm{K} 1}$ in type A cells results in membrane hyperpolarization and virtual quiescence in the dark.

\section{Transient $\mathbf{C a}^{2+}$ current}

Previous reports attest that the photoreceptors express two distinct $\mathrm{Ca}^{2+}$ currents, transient $\left(I_{\mathrm{Cat}}\right)$ and sustained $\left(I_{\mathrm{Cas}}\right)$ currents, and that no significant differences were observed in the level of expression of the two currents in the two cell types (Yamoah and Crow, 1996). The transient current is classified as a T-like current (Nowycky et al., 1985) because it is activated at low voltages, has a rapid onset, is inactivated at a relatively faster rate than is the sustained $\mathrm{Ca}^{2+}$ current, and is selectively blocked by $\mathrm{Ni}^{2+} . I_{\text {Cat }}$ contributes to rhythmic membrane spike activity in the type $\mathrm{B}$ photoreceptors, based on the evidence that $\mathrm{Ni}^{2+}$ alters the frequency and phasic properties of spontaneous activity of the cells. The voltage dependence of both the activation and inactivation of $I_{\mathrm{Cat}}$ revealed the existence of a window current at -50 to $-30 \mathrm{mV}$, suggesting that at rest and during the repolarization 
A

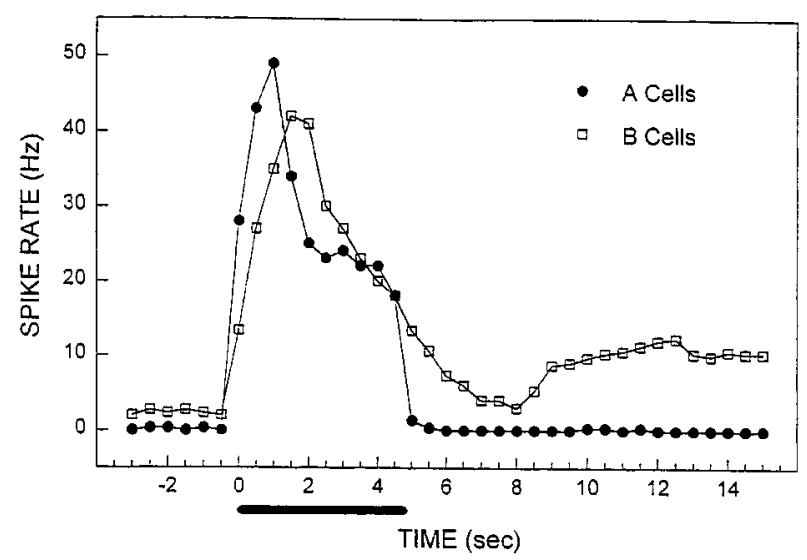

B

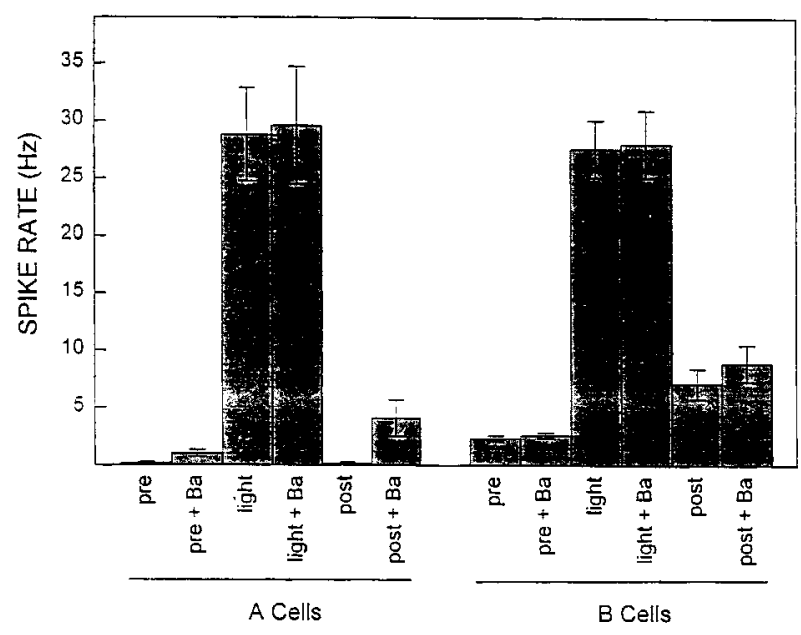

Figure 8. Effects of $\mathrm{Ba}^{2+}$ on spike rates of type A and B cells. $A$, Profile of electrical activity of type $\mathrm{A}$ and $\mathrm{B}$ photoreceptors before and after stimulation with a $5 \mathrm{sec}$ light stimulus. As seen in previous figures, the B cells retained spontaneous activity after the light was turned off. $B$, Histograms generated from five $\mathrm{A}$ and $\mathrm{B}$ photoreceptors. $\mathrm{Ba}^{2+}(1 \mathrm{mM})$ increased the spike rate of type A cells approximately 10-fold from $0.2 \pm$ 0.2 to $2.2 \pm 1.1 \mathrm{~Hz}$. However, the light-elicited spike rate remained virtually the same in the presence or absence of $\mathrm{Ba}^{2+}$. The postlight electrical activity of the $\mathrm{A}$ cells was enhanced further in $\mathrm{Ba}^{2+}$-containing artificial seawater than in normal artificial seawater. In contrast, $\mathrm{Ba}^{2+}$ produced no significant change in spike rates in type B cells both in the pre- and postlight conditions. Prelight ( pre) corresponds to 20 min of dark adaptation, and postlight (post) corresponds to $2 \mathrm{~min}$ after light stimulation.

phase of a generator potential, $I_{\text {Cat }}$ may contribute to the total depolarization-induced currents.

\section{Inward rectifiers}

Evidence of the distinction between $I_{h}$ and $I_{\mathrm{K} 1}$ is as follows. (1) $I_{h}$ was activated with time, whereas activation of $I_{\mathrm{K} 1}$ was timeindependent. (2) $I_{h}$ was permeable to both $\mathrm{Na}^{+}$and $\mathrm{K}^{+}$, whereas $I_{\mathrm{K} 1}$ was relatively $\mathrm{K}^{+}$-selective. (3) $\mathrm{Ba}^{2+}$ selectively blocked $I_{\mathrm{K} 1}$ without having any blocking action on $I_{h}$. (4) The kinetics of block of the two currents by monovalent cations was different. From these data, we conclude that two distinct inward-rectifying currents exist in Hermissenda photoreceptors. The existence of $\mathrm{K}^{+}$selective and $\mathrm{Na}^{+} / \mathrm{K}^{+}$-selective inward rectifier currents in seem- ingly homogeneous cells has been reported in frog hair cells (Holt and Eatock, 1995) and cardiac myocytes (Wu et al., 1991). It is worth noting that in the right atrium of cats, $\sim 90 \%$ of myocytes that exhibit spontaneous pacemaker activity also express $I_{h}$-like currents called $I_{f}$, whereas approximately the same population of quiescent cells was found to exhibit $I_{\mathrm{K} 1}$-like currents $(\mathrm{Wu}$ et al., 1991). Presumably, the predominance of $I_{h}$-like current is one of the requirements for spontaneous activity, whereas quiescence cells may require $I_{\mathrm{K} 1}$-like background current.

The properties of the inward-rectifying currents in the photoreceptors account for some of the characteristic properties of the photoreceptors. Specifically, $I_{h}$ shares features that are consistent with spontaneous pacemaker activity in the B cells. (1) The activation threshold of $I_{h}(-40$ to $-50 \mathrm{mV})$ is compatible with the induction of afterdepolarization during the repolarization phase of action and generator potentials. Also, the permeation properties of the channels $\left(\mathrm{Na}^{+}\right.$and $\left.\mathrm{K}^{+}\right)$and the corresponding $E_{\mathrm{rev}}$ of $I_{h}$ (approximately $-40 \mathrm{mV}$ ) indicate that at rest (approximately $-50 \mathrm{mV}$ ) $I_{h}$ promotes membrane depolarization. (2) The timedependent activation kinetics of $I_{h}$ is consistent with the pacing of type B cells after dark adaptation $(\sim 3 \mathrm{~Hz})$; however, as depicted in Figure 6, it is clear that spontaneous activity of the B cells results from the transient $\mathrm{Ca}^{2+}$ current as well. (3) The fact that $I_{h}$ blocked by $\mathrm{Cs}^{+}$reduces the frequency of spontaneous activity is in agreement with the hypothesis that $I_{h}$ contributes to the initiation of spontaneous activity in the B cells. The present hypothesis predicts that in vivo $I_{h}$ is activated by an ensemble of synaptic inhibitory potentials from adjacent photoreceptors and vestibular neurons (Rogers et al., 1994). Activation of $I_{h}$ is expected to follow membrane repolarization of action and generator potentials. If inhibitory input from the cells adjacent to type $B$ cells is stronger than that from those adjacent to type A cells, as suggested by Alkon and Fuortes (1972), then $I_{h}$ in the B cells will be poised to induce an enhanced membrane depolarization to produce tonic activity. Because $I_{h}$ exhibits no inactivation at potentials close to the resting potential of the B cells (approximately $-50 \mathrm{mV}$ ), activation of $I_{h}$ can be cumulative, thus resulting in phasic depolarization of the membrane potential. As seen in Figure $6 A$, after suppressing the transient $\mathrm{Ca}^{2+}$ currents with $\mathrm{Ni}^{2+}$, nonphasic spike activity in the $\mathrm{B}$ cells was transformed into a phasic firing pattern that was abolished after application of $\mathrm{Cs}^{+}$. Thus, the properties of $I_{h}$ can account, at least in part, for the reported properties of the B cells.

$I_{h}$ recorded from the photoreceptors exhibits many of the properties reported for the current in leech heart interneurons (Angstadt and Calabrese, 1989), neonatal spinal motor neurons (Takahashi, 1990), thalamic relay neurons (Huguenard and McCormick, 1992), and vertebrate photoreceptors (Maricq and Korenbrot, 1990). In addition, there are remarkable similarities between the properties of $I_{h}$ and those of the currents termed $I_{f}$ in cardiac pacemaker cells (Yanagihara and Irisawa, 1980; DiFrancesco, 1985) and $I_{q}$ in hippocampal neurons (Halliwell and Adams, 1982; Maccaferri et al., 1993). Permeation of the channels by $\mathrm{Na}^{+}$and $\mathrm{K}^{+}$and sensitivity to $\mathrm{Cs}^{+}$block are a few examples of the common features shared by these hyperpolarizationactivated currents. Furthermore, cells that express these hyperpolarization-activated currents invariably exhibit some form of membrane potential oscillations. Thus, the present findings on the contribution of $I_{h}$ to type B photoreceptor spontaneous activity are consistent with previous reports on the functions of $I_{h}$. Although many of the characteristics of $I_{h}$ are similar to those reported for hyperpolarizing-activated currents in other 


\begin{tabular}{|c|c|c|c|c|c|c|c|}
\hline Reference & Tissue & Current & $\begin{array}{l}\mathrm{V}_{1 / 2} \\
(\mathrm{mV})\end{array}$ & $\begin{array}{l}K \\
(\mathrm{mV})\end{array}$ & Charge carrier & Sensitivity & Functions \\
\hline \multirow[t]{2}{*}{ Yamoah et al. (this paper) } & Hermissenda photoreceptors & $I_{h}$ & -74 & 15.5 & $\mathrm{Na}^{+} / \mathrm{K}^{+}$ & $\mathrm{Cs}^{+}$ & Spontaneous activity \\
\hline & & $I_{\mathrm{k} 1}$ & -90 & 12.7 & $\mathrm{~K}^{+}$ & $\mathrm{Ba}^{2+}$ & Membrane hyperpolarization \\
\hline Hestrin (1987) & Salamander rod photoreceptors & $I_{h}$ & -67.2 & 7.2 & $\mathrm{Na}^{+} / \mathrm{K}^{+}$ & $\mathrm{Cs}^{+}$ & $?$ \\
\hline \multicolumn{8}{|l|}{ Maricq and Korenbrot } \\
\hline$(1990)$ & Inner segment of retinal cones & $I_{h}$ & -79 & 7.5 & $\mathrm{Na}^{+} / \mathrm{K}^{+}$ & $\mathrm{Cs}^{+}$ & Membrane depolarization \\
\hline Eng et al. (1990) & Optic nerve & $I_{h}$ & $?$ & $?$ & $\mathrm{Na}^{+} / \mathrm{K}^{+}$ & $\mathrm{Cs}^{+}$and $\mathrm{Ba}^{2+}$ & Enhances membrane excitability \\
\hline Newman (1993) & Retinal glial cells & $I_{\mathrm{k} 1}$ & $?$ & $?$ & $\mathrm{~K}^{+}$ & $\mathrm{Ba}^{2+}$ & $\mathrm{K}^{+}$homeostasis \\
\hline \multirow[t]{2}{*}{ Holt and Eatock (1995) } & Frog saccular hair cells & $I_{h}$ & -90 & 9.6 & $\mathrm{Na}^{+} / \mathrm{K}^{+}$ & $\mathrm{Cs}^{+}$ & Electrical resonance \\
\hline & & $I_{\mathrm{k} 1}$ & -86 & 5.2 & $\mathrm{~K}^{+}$ & $\mathrm{Ba}^{2+}$ & Membrane hyperpolarization \\
\hline $\begin{array}{l}\text { Angstadt and Calabrese } \\
\text { (1989) }\end{array}$ & $\begin{array}{l}\text { Heart interneurons of } \\
\text { medicinal leech }\end{array}$ & $I_{h}$ & -58 & $?$ & $\mathrm{Na}^{+} / \mathrm{K}^{+}$ & $\mathrm{Cs}^{+}$ & Rhythmic bursting activity \\
\hline \multirow[t]{2}{*}{ Wu et al. (1991) } & Cat atrial myocytes & $I_{f}$ & -83 & 7 & $\mathrm{Na}^{+} / \mathrm{K}^{+}$ & $\mathrm{Cs}^{+}$ & Pacemaker current \\
\hline & & $I_{\mathrm{k} 1}$ & $?$ & $?$ & $\mathrm{~K}^{+}$ & $\mathrm{Ba}^{2+}$ & Membrane hyperpolarization \\
\hline
\end{tabular}

systems, the time course of activation was significantly faster than that for $I_{h}$ and/or $I_{f}$ in other systems; e.g., at $-60 \mathrm{mV}$, the time constant of activation of $I_{h}$ in Hermissenda photoreceptors was $\sim 300 \mathrm{msec}$, whereas values closer to $1 \mathrm{sec}$ have been reported in leech interneurons (Angstadt and Calabrese, 1989), and values from 1 to $3 \mathrm{sec}$ have been documented in sinoatrial node cells (Hagiwara and Irisawa, 1989; Zhou and Lipsius, 1992). The time course of activation is expected to affect the beat frequency of spontaneously active cells. However, a direct correlation between the activation of $I_{h}$ and the frequency of membrane activity will be unlikely in the photoreceptors, where multiple conductances dictate baseline activity. Interestingly, the time course of activation of $I_{h}$ in photoreceptors is similar to that of $I_{h}$ in saccular hair cells (Holt and Eatock, 1995). Similar to the photoreceptors, saccular hair cells express two inward-rectifying currents, one $\mathrm{Cs}^{+}$- and the other $\mathrm{Ba}^{2+}$-sensitive (Table 1).

Inward rectification promotes membrane depolarization if the $E_{\text {rev }}$ of the current is positive relative to the resting potential of the cell. The time-independent current $I_{\mathrm{K} 1}$ has permeation properties, which are $\mathrm{K}^{+}$selective, making the $E_{\mathrm{rev}}$ more negative $(-70$ to $-75 \mathrm{mV}$ ) than the recorded resting potential of the photoreceptors (approximately $-50 \mathrm{mV}$ ). In cells that predominantly express $I_{\mathrm{K} 1}$, the current acts as a background current that tends to restore the resting potential of the photoreceptors. Relatively high expression of $I_{\mathrm{K} 1}$ in A cells is consistent with the relatively hyperpolarized state of the A cells at rest and the lack of spontaneous activity in the A cells during dark adaptation.

Combined techniques of molecular cloning and electrophysiological studies of cloned channels in heterologous expression systems have identified several types of inward rectifier channels (Bond et al., 1994). These cloned channels exhibit distinct kinetics and pharmacology. It is of interest to correlate the properties of these expressed channels to the native currents recorded in a more physiological system, keeping in mind the possible differences attributable to heteromultimerization and subunit coassembly in the native systems. Emerging data on the inward rectifier currents in both vertebrate and invertebrate systems clearly indicate expression of these currents, namely $I_{h}$ - and $I_{\mathrm{K} 1}$-like currents, in maintaining similar functions in seemingly diverse systems, spanning from invertebrates to vertebrates.

\section{REFERENCES}

Abrams TW (1985) Activity-dependent presynaptic facilitation: an associative mechanism in Aplysia. Cell Mol Neurobiol 5:123-145.

Acosta-Urquidi J, Crow T (1993) Differential modulation of voltagedependent currents in Hermissenda type B photoreceptors by serotonin. J Neurophysiol 70:541-548.

Acosta-Urquidi J, Crow T (1995) Characterization of voltage-activated currents in Hermissenda type B photoreceptors. J Neurosci 15:319-332.

Alkon DL (1979) Voltage-dependent calcium and potassium ion conductances: a contingency mechanism for an associative learning model. Science 205:810-816.

Alkon DL, Fuortes MGF (1972) Responses of photoreceptors in Hermissenda. J Gen Physiol 60:639-649.

Alkon DL, Sakakibara M, Forman R, Harrigan J, Lederhendler I, Farley J (1985) Reduction of two voltage-dependent $\mathrm{K}^{+}$currents mediates retention of a learned association. Behav Neural Biol 44:278-300.

Alkon DL, Sanchez-Andres JV, Ito E, Oka K, Yoshioka T, Collin C (1992) Long-term transformation of an inhibitory into excitatory GABAergic synaptic response. Proc Natl Acad Sci USA 89:11862-11866.

Angstadt JD, Calabrese RL (1989) A hyperpolarization-activated inward current in heart interneurons of the medicinal leech. J Neurosci 9:2846-2857.

Bond CT, Pessia M, Xia MX, Lagrutta A, Kavanaugh MP, Adelman JP (1994) Cloning and expression of a family of inward rectifier potassium channels. Receptors Channels 2:183-191.

Brezina C, Evans G, Weiss KR (1994) Characterization of the membrane ion currents of a model molluscan muscle, the accessory radula closer muscle of Aplysia californica. Hyperpolarization-activated currents. J Neurophysiol 72:2093-2112.

Crow T (1988) Cellular and molecular analysis of associative learning and memory in Hermissenda. Trends Neurosci 11:136-142.

Crow T, Alkon DL (1980) Associative behavioral modification in Hermissenda; cellular correlates. Science 209:412-414.

DiFrancesco D (1985) The cardiac hyperpolarizing-activated current $\mathrm{I}_{\mathrm{f}}$; origins and developments. Prog Biophys Mol Biol 46:163-183.

Eng DL, Gordon TR, Kocsis JD, Waxman SG (1990) Current-clamp analysis of a time-dependent rectification in rat optic nerve. J Physiol (Lond) 421:185-202.

Farley J, Alkon DL (1982) Associative neural and behavioral change in Hermissenda; consequences of nervous system orientation for light- and pairing-specificity. J Neurophysiol 48:785-807.

Farley J, Richards WG, Grover LM (1990) Associative learning changes intrinsic to Hermissenda type A photoreceptors. Behav Neurosci 104:135-152.

Hagiwara N, Irisawa H (1989) Modulation by intracellular $\mathrm{Ca}^{2+}$ of the hyperpolarization-activated inward current in rabbit single sino-atrial node cells. J Physiol (Lond) 409:121-141.

Halliwell JV, Adams PR (1982) Voltage-clamp analysis of muscarinic excitation in hippocampal neurons. Brain Res 250:71-92. 
Hamill OP, Marty A, Neher E, Sakmann B, Sigworth JF (1981) Improved patch-clamp techniques for high resolution current recording from cells and cell-free membrane patches. Pflügers Arch 391:85-100.

Hestrin S (1987) The properties and function of inward rectification in rod photoreceptors of the tiger salamander. J Physiol (Lond) 390:319-333.

Hille B (1992) Ionic channels of excitable membranes, 2nd edition, pp 341-347. Sunderland, MA: Sinauer.

Holt JR, Eatock RA (1995) Inwardly rectifying currents of saccular hair cells from the leopard frog. J Neurophysiol 73:1484-1502.

Huguenard JR, McCormick DR (1992) Simulation of the currents involved in rhythmic oscillations in thalamic relay neurons. J Neurophysiol 62:1373-1399.

Jester JM, Campbell WL, Sejnowski TJ (1995) Associative EPSP-spike potentiation induced by pairing orthodromic and antidromic stimulation in rat hippocampal slices. J Physiol (Lond) 484:689-705.

Kurachi Y (1985) Voltage-dependent activation of the inward-rectifier potassium channel in the ventricular cell membrane of guinea-pig heart. J Physiol (Lond) 366:365-385.

Llinas R, Yarom Y (1981) Electrophysiology of mammalian inferior olivary neurons in vitro: different types of voltage-dependent ionic conductances. J Physiol (Lond) 315:549-567.

Maccaferri G, Mangoni M, Lazzari A, DiFrancesco D (1993) Properties of hyperpolarization-activated current in rat hippocampal CA1 pyramidal cells. J Neurophysiol 69:2129-2136.

Maricq AV, Korenbrot JI (1990) Inward rectification in the inner segment of single retinal cone photoreceptors. J Neurophysiol 64:1917-1928.

Matzel LD, Rogers RF (1993) Postsynaptic calcium, but not cumulative depolarization, is necessary for the induction of associative plasticity in Hermissenda. J Neurosci 13:5029-5043.

Newman EA (1993) Inward-rectifying potassium channels in retinal glial (Muller) cells. J Neurosci 13:3333-3345.

Nowycky AC, Fox AP, Tsien RW (1985) Three types of neuronal calcium channels with different calcium agonist sensitivity. Nature $316: 440-443$.

Ohmori H (1978) Inactivation kinetics and steady-state current noise in the anomalous rectifier of tunicate egg cell membranes. J Physiol (Lond) 281:77-99.
Preston RR, Saimi Y, Kung C (1992) Calcium current activated upon hyperpolarization of Paramecium tetraurelia. J Gen Physiol 100:233-251.

Rogers RF, Fass DM, Matzel LD (1994) Current, voltage and pharmacological substrates of a novel GABA receptor in the visual-vestibular system of Hermissenda. Brain Res 650:93-106.

Silver MR, DeCoursey TE (1990) Intrinsic gating of inward rectifier in bovine pulmonary artery endothelial cells in the presence or absence of internal $\mathrm{Mg}^{2+}$. J Gen Physiol 96:109-133.

Standen NB, Stanfield PR (1979) Potassium depletion and sodium block of potassium currents under hyperpolarization in frog sartorius muscle. J Physiol (Lond) 294:497-520.

Takahashi T (1990) Inward rectification in neonatal rat spinal motoneurons. J Physiol (Lond) 423:47-62.

Woodhull AM (1973) Ionic blockage of sodium channels in nerve. J Gen Physiol 61:687-708.

Wu J, Vereecke J, Carmeliet E, Lipsius SL (1991) Ionic currents activated during hyperpolarization of single right atrial myocytes from cat heart. Circ Res 68:1059-1069.

Yamaguchi K, Nakajima Y, Nakajima S, Stanfield PR (1990) Modulation of inward rectifying channels by substance $\mathrm{P}$ in cholinergic neurons from rat brain in culture. J Physiol (Lond) 426:499-520.

Yamoah EN, Crow T (1994) Two components of calcium currents in the soma of photoreceptors of Hermissenda. J Neurophysiol 72:1327-1336.

Yamoah EN, Crow T (1996) Protein kinase and G-protein regulation of $\mathrm{Ca}^{2+}$ currents in Hermissenda photoreceptors by 5-HT and GABA. J Neurosci 16:4799-4809.

Yamoah EN, Kuzirian A (1994) Effects of GABA on outward currents in Hermissenda photoreceptors. Biol Bull 187:265-266.

Yamoah EN, Kuzirian AM, Sanchez-Andres JV (1994) Calcium current and inactivation in identified neurons in Hermissenda crassicornis. J Neurophysiol 72:2196-2208.

Yanagihara K, Irisawa H (1980) Inward current activated during hyperpolarization in the rabbit sinoatrial node cell. Pflügers Arch 185:11-19.

Zhou Z, Lipsius S (1992) Properties of the pacemaker current $\left(\mathrm{I}_{\mathrm{f}}\right)$ in latent pacemaker cells isolated from cat right atrium. J Physiol (Lond) 453:503-523. 